\title{
Prediction of effects of dairy selection indexes on methane emissions
}

\author{
X. Zhang, * () P. R. Amer, (1) G. M. Jenkins, J. A. Sise, B. Santos, and C. Quinton (1) \\ AbacusBio Limited, Dunedin 9058, New Zealand
}

\begin{abstract}
Global warming caused by greenhouse gas emissions is a threat to the survival of humans and other organisms living on Earth. The greenhouse gases released from the dairy sector of New Zealand accounted for 18.2 Mt of carbon dioxide equivalent $\left(\mathrm{CO}_{2}\right.$-eq) in 2016, mainly from methane generated by enteric fermentation in the rumen of milking cows and their replacement stock. A productivity commission established by the New Zealand government in 2018 estimated that methane emissions from livestock needed to be reduced from 2016 levels by 10 to $22 \%$ by 2050 (i.e., 2.8 to 6.1 million $\mathrm{t}$ lower), so as to restrict future increases in global temperature to less than $2^{\circ} \mathrm{C}$. In this study, we evaluated genetic effects of 8 traits included in the New Zealand national dairy breeding objective, on 3 types of methane emissions metrics: gross methane emissions per dairy cow per year $(E)$, methane emissions per hectare $(E H)$, and methane emissions intensity per milk protein equivalents $(E I)$, as carbon dioxide equivalents. These effects were then aligned with recent genetic changes in these traits brought about by breeding schemes, so that the overall genetic trend for each metric into the future was estimated. The results showed that $E H$ and $E I$ are currently being reduced at rates of $-2.31 \mathrm{~kg}$ of $\mathrm{CO}_{2}$-eq per hectare per cow per year (current average is 6,915 $\mathrm{kg}$ of $\mathrm{CO}_{2}$-eq/ha per cow per year) and $-0.04 \mathrm{~kg}$ of $\mathrm{CO}_{2}$-eq per $\mathrm{kg}$ of milk protein equivalents per cow per year, respectively (current average is $9.7 \mathrm{~kg}$ of $\mathrm{CO}_{2}$-eq/ milk protein-eq per cow per year). These improvements directly reflect increased production efficiency through selection for farm profitability. If the pastureland area in New Zealand remains the same, at the same productivity and with no increase in supplementation rates from external land sources, in 20 years gross emissions would be reduced by only $0.6 \%$, or $89 \mathrm{Mt}$. Increased production efficiency will likely result in corresponding changes to the stocking rate, to fully utilize the pasture resource available, and might further encour-
\end{abstract}

Received May 10, 2019.

Accepted August 20, 2019.

*Corresponding author: lzhang@abacusbio.co.nz age a greater rate of intensification via supplementary feeding. Both consequences of current genetic selection could negate any benefits for the national greenhouse gas inventory. New selection criteria for reduced methane production are needed to help achieve New Zealand's national methane reduction targets.

Key words: emissions intensity, methane, greenhouse gas, hectare, dairy

\section{INTRODUCTION}

There is increasing global pressure to lower greenhouse gas (GHG) emissions and improve environmental sustainability. New Zealand has among the highest per-person GHG emissions in the world, due to the large agriculture sector relative to population size, which accounts for $49 \%$ of the national total GHG emissions (New Zealand Productivity Commission, 2018), of which New Zealand's dairy sector accounts for $18.2 \mathrm{Mt}$ of carbon dioxide equivalents $\left(\mathbf{C O}_{2}\right.$-eq). Methane is responsible for around $70 \%$ of agricultural emissions and is caused primarily by enteric fermentation in the digestive tracts of ruminant animals (Ministry for the Environment, 2019). The New Zealand Productivity Commission (2018) has estimated that, by 2050, methane emissions from livestock need to be reduced by 10 to $22 \%$ of 2016 levels, to ensure that New Zealand does not contribute to additional warming beyond current levels. This equals a reduction of 2.8 to $6.1 \mathrm{Mt}$.

In animal breeding, many studies have indicated potential to genetically select animals with lower gross methane emissions (Pickering et al., 2015; Rowe et al., 2015; Jonker et al., 2018). However, in dairy breeding, gross methane levels are correlated unfavorably with milk component traits such as milk protein and milk fat (Pickering et al., 2015; Breider et al., 2018; Kandel, 2018); therefore, selecting for lower gross methane emissions could both sacrifice production efficiency and substantially increase production costs of dairy products, which are in growing demand globally (Capper et al., 2009).

Pickering et al. (2015) concluded that methane emissions in Holstein dairy cattle are strongly correlated with DMI (genetic correlation $0.99 \pm \mathrm{SE} 0.00$ ). Amer et 
al. (2018) proposed a methodology framework that can be used to quantify gross methane emissions and emissions intensity per unit of product output arising from genetic progress in conventional genetic traits. Changes in methane output are modeled as a direct consequence of the changes in DMI due to genetic changes in each of the traits, with changes in selection preferences resulting in changes to predicted methane outcomes. When applied within the Irish Cattle Breeding Cattle Federation dairy objective (Amer et al., 2018), this methodology resulted in an estimated 5 to $15 \%$ reduction in total $\mathrm{kg}$ of $\mathrm{CO}_{2}$-eq over 25 years. This methodology was also applied to Irish beef cattle selection indexes (Quinton et al., 2018), where the predicted reduction in methane emissions per unit of product was 5 to $11 \%$ in 20 years. These predictions were based on genetic trends in conventional genetic traits that farmers currently select on, so the profitability consequences are minimal.

New Zealand Animal Evaluation Limited oversee the methodology used to determine the National Breeding Objective (NBO) for New Zealand dairy breeding, to breed dairy cows that efficiently convert feed into profit. Breeding worth is the index used to rank dairy cattle according to their ability to meet the NBO. Currently, the breeding objective includes 8 traits, with relative weightings based on their estimated contribution to farm profitability: milk protein, milk fat, milk volume, live weight, SCS, fertility, survival, and BCS.

The objectives of this study were (1) to investigate whether the current breeding strategy would need to change if it is to accommodate the national methane emissions reduction policy; (2) to compare metrics for gross methane emissions, methane emissions per hectare, and methane emissions intensity per product, in the context of the New Zealand dairy industry; and (3) to investigate the likely changes to these methane emissions metrics that will occur in the future if current rates of genetic change in traits making up the NBO continue for the next 20 years.

\section{MATERIALS AND METHODS}

A primary assumption was made, that the amount of methane emitted by an animal is proportional to the energy consumed by that animal from feed intake. Therefore, the methods used here investigate the relationship between genetic gains in each trait and the associated changes in feed energy requirements.

\section{Conversion of Methane Emissions and Energy from Feed Intake}

The carbon dioxide equivalent per unit of energy ( $\mathrm{kg}$ of $\mathrm{CO}_{2}-\mathrm{eq} / \mathrm{kg}$ of $\mathrm{DM}$ ) used in this study was 0.583 $\mathrm{kg}$ of $\mathrm{CO}_{2}$-eq/ $\mathrm{kg}$ of DM (Fennessy et al., 2018). This value has been used in various related studies (Amer et al., 2018; Quinton et al., 2018) and aligns closely with values used in the calculation of national livestock GHG inventories. The energy in pasture was estimated as 10.42 MJ of ME per kg of DM. When cows are on the milking platform (the term used in New Zealand for farmland within walking distance of the milking facility), either milking or preparing to milk during winter, feed energy is sourced from a mixture of pasture, forage, and concentrates - hence, 11.26 MJ of ME $/ \mathrm{kg}$ of DM. During the dry-off period, when cows are away from the milking platform (off platform), the off-platform feed during winter also includes crops; hence, the energy was estimated as $11.71 \mathrm{MJ}$ of $\mathrm{ME} / \mathrm{kg}$ of DM (J. A. Sise, AbacusBio, Dunedin, New Zealand, personal communication; Table 1).

We constructed 3 sets of equations to estimate methane emissions from different perspectives. These include the gross emissions per animal, emissions per hectare used for dairy farming (important when considering the national inventory), and emissions intensity per milk protein equivalents (milk protein-eq). The changes of the above 3 terms were derived, respective to the changes in trait breeding values, to show the effects of breeding on methane emissions.

\section{Models for Gross Methane Emissions}

The gross methane emissions, as $\mathrm{CO}_{2}$ equivalents, produced by a breeding cow per year before genetic change $(\boldsymbol{E})$ is a product of number of animals, feed intake, and a conversion coefficient of feed intake energy to methane emissions across different stock classes, as follows:

$$
E=\sum_{i=1}^{c} n_{i} F_{i} \alpha_{i} Y_{i},
$$

where $E$ is the total amount of methane emitted per breeding cow across $c$ stock classes included in the methane reduction objective definition, before any genetic change; $n_{i}$ is the number of animals of stock class $i$ per breeding cow in an average dairy farm system; $F_{i}$ is the total feed intake (as DM) energy in MJ of ME per animal of stock class $i, \alpha_{i}$ is the mass of carbon dioxide equivalent of methane emissions per MJ of ME in the food eaten by animals of this stock class (i.e., $0.583 \mathrm{~kg}$ of $\mathrm{CO}_{2}$-eq $/ \mathrm{kg}$ of DM; Fennessy et al., 2018); and $Y_{i}$ is an indicator variable that takes a value of 1 if stock class $i$ should be considered in the definition of total methane emitted, and a value of 0 otherwise.

Variables $n_{i}$ and $F_{i}$ are functions of at least some of the genetic traits $(g)$. The changes in gross $\mathrm{CO}_{2}$-eq 
Table 1. Key assumptions used in the calculations of methane emissions intensity weightings for the New Zealand dairy industry

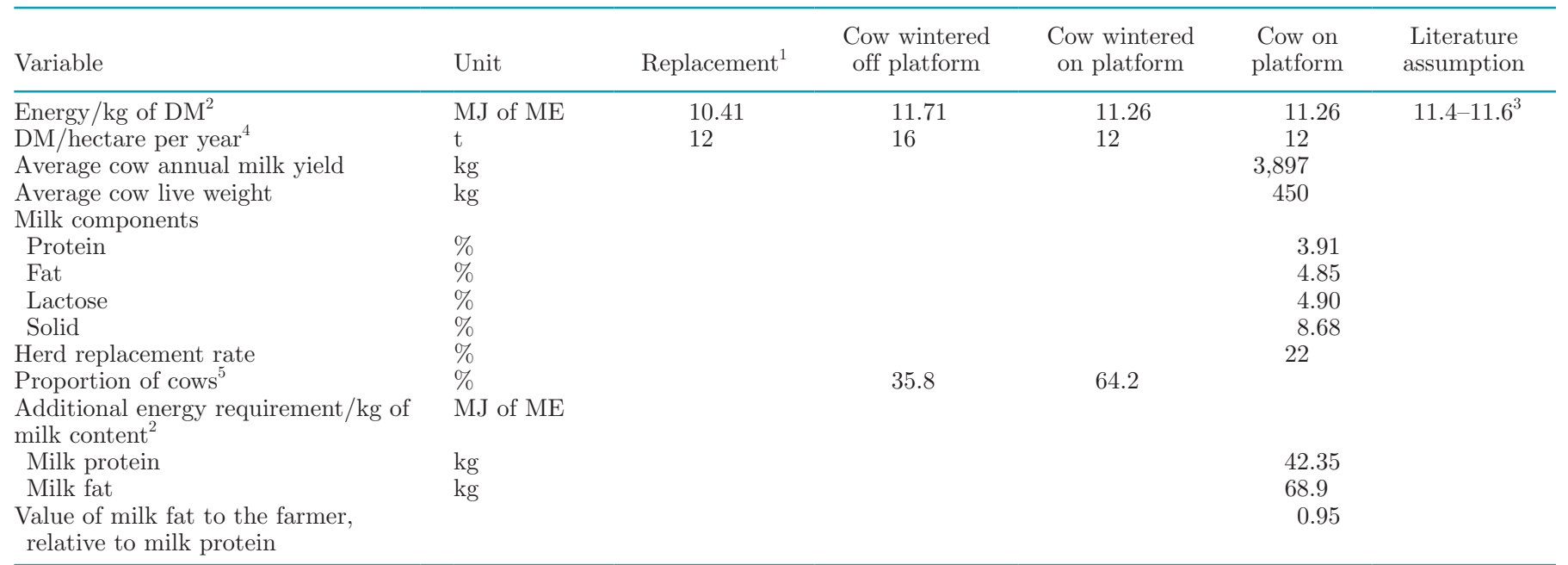

${ }^{1}$ From birth to first calving.

${ }^{2} \mathrm{Nicol}$ and Brookes (2007), p. 161.

${ }^{3}$ Bell et al. (2016).

${ }^{4}$ Jude Sise, AbacusBio, Dunedin, New Zealand, personal communication.

${ }^{5}$ DairyNZ (2017).

per cow per annum from genetic improvement $(\boldsymbol{G} \boldsymbol{V})$ can therefore be obtained by finding the unit change in the number of animals and DM when the genetic trait changes by 1 unit, obtained by calculating the first derivative $(d)$ of $E$ with respect to genetics, as follows:

$$
\begin{aligned}
& G V=\frac{d E(g)}{d g} \\
& =\frac{d \sum_{i=1}^{c} n_{i}(g) F_{i}(g) \alpha_{i} Y_{i}}{d g} \\
& =\sum_{i=1}^{c} \alpha_{i} Y_{i}\left[\frac{d n_{i}(g)}{d g} F_{i}+\frac{d F_{i}(g)}{d g} n_{i}\right] .
\end{aligned}
$$

\section{System Gross Emissions Before Genetic Change}

The parameters used to estimate $E$ are summarized in Table 2. The gross $\mathrm{CO}_{2}$-eq before genetic change is the direct product of the number of animals and the $\mathrm{CO}_{2}$-eq emitted per animal from feed consumption (Equation [1]). This is independent of breeding traits. For every lactating cow, methane emissions must be aggregated for the cow, as well as for the replacements required on average per lactating cow to maintain the milking herd. The average replacement rate required per breeding cow can be taken as the proportion of the herd in their first parity and is approximately $22 \%$ (DairyNZ, 2017). The proportion of cows wintered off versus on platform across the country (Table 1) were $35.8 \%$ and
$64.2 \%$ (DairyNZ, 2017). The feed requirement for each animal class, $F_{i}$, was based on nutritional equations as developed by Rattray et al. (2007) and Quinton et al. (2018), which calculated nutrient requirements of a cow or replacement based on live weight, milk production, live weight gain, mobilization, and stage of gestation for weighted average cows across breeds.

\section{Changes in Feed Intake by Stock Class and Breeding Trait}

For each of the traits, extra energy may be required for each 1-unit increase in the trait. Milk traits are only expressed by lactating cows on the milking platform. The amount of energy required to produce a 1-L increase in milk was calculated as the equivalence of the energy required to produce $1 \mathrm{~kg}$ extra of lactose multiplied by the lactose composition of $1 \mathrm{~L}$ of milk (4.9\%). This avoids double counting of energy required for milk fat and protein when using the total milk energy requirements.

The live weight effect on energy change is different for cows and replacements. The average live weight of New Zealand cows was assumed to be $450 \mathrm{~kg}$. The daily maintenance energy requirements for a lactating breeding cow to maintain an extra $1 \mathrm{~kg}$ of live weight (LW) were calculated as the first derivative of the formula for daily maintenance energy requirements from Rattray et al. (2007): $0.56 \mathrm{MJ}$ of $\mathrm{ME} \times \mathrm{LW}^{0.75}$. This energy requirement was then multiplied by the days across the 
year that were relevant to that stock class; for example, for cows on the milking platform, the energy required to maintain an extra $1 \mathrm{~kg}$ of live weight was multiplied by $305 \mathrm{~d}$ ( $270 \mathrm{~d}$ lactation plus $35 \mathrm{~d}$ before calving). For wintered cows, the energy requirement was multiplied by $60 \mathrm{~d}$. The effect of cow mature weight on replacement heifer feed requirements is the sum of extra maintenance, growth, and pregnancy feed requirements for a replacement from birth to first calving. The extra energy requirements to grow to a $1-\mathrm{kg}$ heavier target mature weight were calculated as the difference in the total energy requirements between a "base" replacement and a replacement as New Zealand average that gained $1 \mathrm{~kg}$ of extra live weight at the first parturition (Table 2).

Residual survival affects the methane emissions because it changes the herd structure to be older and older cows have higher energy requirements than younger lactating cows driven by milk yield, live weight and growth differences. At the same time, improved residual survival reduces the feed required for rearing of replacements, simply because fewer replacements are required. The calculation example for cows on the milking platform is shown in Supplemental Table S1 (https: //doi.org/10.3168/jds.2019-16943). The $\frac{d F(g)}{d g}$ (feed energy requirements per extra survival day) of 0.96 was derived from the average feed intake per cow relative to a mature cow, divided by average lifespan per survival. Similar methods were applied to other stock classes.

Somatic cell score does not influence the feed requirements and hence was not modeled as having any direct effect on emissions per animal. Higher fertility affects feed requirements through its direct effect on survival, affecting the extra feed for proportionally older and higher-producing cows and reducing feed for replacement heifers in exactly the same way as modeled for residual survival. The genetic regression of survival on fertility was derived assuming a genetic correlation between total survival and fertility of 0.6 , a genetic standard deviation for fertility of $5.7 \%$ (Harris, 2005) and for total survival of $2.65 \mathrm{~d}$. Then the genetic regression will be $0.6 \times 264.55 / 5.7 \%=27.85$ (Amer et al., 2013). Improved herd fertility in seasonal calving systems also leads to more earlier-calving cows and thus longer lactation, as dry-off is typically at a fixed date in the seasonal calving system of New Zealand.

Total extra feed energy of 36 MJ of ME required with each $1 \%$ increase in fertility was calculated from (1) more older cows through increased survival, as described in the previous paragraph, and (2) higher proportion of early-calving cows at the beginning of the calving season that go on to have longer lactations and require more energy than their late-calving contemporaries.

A higher BCS means either or both of the following: (1) the cow requires less feed to regain the lost BCS during winter through feeding allowances (Byrne et al., 2013), or (2) the cow has a longer lactation and thus higher milk production when farmers choose to dry off higher-BCS cows later than lower-BCS cows. A higher BCS is assumed to require extra energy for milking cows on platform, because a proportion of cows with higher BCS would be dried off later than those with low BCS and therefore would have sustained energy requirements at the end of the milking period. The extra energy through 1-unit increase of BCS for prolonged lactation was assumed to be 1,672 MJ of ME/breeding

Table 2. Stock class-specific parameters calculating gross methane emissions [kg of $\mathrm{CO}_{2}$-equivalent (eq) emissions/breeding cow per year, $\left.E\right]$, hectare per breeding cow $(H)$, and emissions per hectare $\left(\mathrm{kg}\right.$ of $\mathrm{CO}_{2}$-eq emissions/ha, $\left.E H\right)$ before genetic change

\begin{tabular}{|c|c|c|c|c|c|}
\hline Parameter & Replacement & Cow wintered off platform & Cow wintered on platform & Cow on platform & Total \\
\hline$F^{2}$ & 42,359 & 4,946 & 4,946 & 44,654 & \\
\hline$\alpha^{3}$ & 0.056 & 0.050 & 0.052 & 0.052 & \\
\hline$\pi^{4}$ & 1 & 1 & 0.91 & 0.91 & \\
\hline$\gamma^{5}$ & 345 & 506 & 371 & 371 & \\
\hline$d^{6}$ & 690 & 60 & 60 & 305 & \\
\hline$E H$ & - & - & - & - & 6,915 \\
\hline
\end{tabular}

${ }^{1}$ Number of animals per stock class per breeding cow.

${ }^{2}$ Feed intake energy (MJ of ME) per stock class per breeding cow.

${ }^{3}$ Parameter converting feed intake into $\mathrm{CO}_{2}$-eq $\left(\mathrm{CO}_{2}\right.$-eq per $\mathrm{MJ}$ of $\mathrm{ME}$ feed eaten).

${ }^{4}$ Proportion of feed supplies from the block of land where the stock class is being run (i.e., pasture and homegrown feeds).

${ }^{5}$ Average feed energy produced (MJ of ME/ha per day) on the land where the stock class is being run.

${ }^{6}$ Number of days the stock class consuming feed supplies from the block of land.

${ }^{7}$ Proportion of feed supplies from the block of land (MJ of ME/ha per day) produced that is eaten. 
cow per year. The average energy for a breeding cow on platform was the summation of the above, weighted by the $40 \%$ of cows utilizing that energy. Similarly, for wintered cows there was a feed savings of 412 MJ of ME by 1-unit higher BCS, weighted by the $60 \%$ of cows in New Zealand utilizing this energy. Note that in the context of genetic improvement, a whole BCS unit would be a very large genetic change, and so these apparently large coefficient values come into context when multiplied by very small genetic trends for BCS over time.

\section{Changes in Stocking Rate by Stock Class and Breeding Trait}

Most breeding traits do not affect the number of animals in a stock class, $\frac{d n(g)}{d g}$. However, genetic changes in survival and fertility both influence the number of replacements required per cow in the main herd. For survival, the change in number of replacements was the reduction in number of replacements required with a 1-day increase in survival, giving a value of 0.00012 fewer replacements (Supplemental Table S1, https:// doi.org/10.3168/jds.2019-16943). For fertility, the stocking rate was affected indirectly from survival as a correlated trait with $27.85 \mathrm{~d}$ of increased survival per $1 \%$ increase in the fertility trait breeding value, as described above. The change in number of replacements required was equivalent to that of survival divided by the genetic regression coefficient for survival on fertility (Table 3). For all other genetic trait $\times$ animal class combinations, coefficient values of 0 indicate that the trait is not expected to change the number of animals present per cow in the main herd.

\section{Models for Methane per Hectare}

Total emissions per cow per annum (Equation [1]) can be expressed as a ratio of the total number of hectares for grazing land required per cow. The total hectares $(H)$ per breeding cow per year in the system, across all stock classes, before genetic change is as follows:

$$
H=\sum_{i=1}^{c} n_{i} F_{i} \pi_{i} \frac{\rho_{i}}{\gamma_{i} d_{i}} X_{i}
$$

where $\pi_{i}$ is the proportion of feed supplied to this stock class from the block of land on which this stock class is being run. Thus $\left(1-\pi_{i}\right)$ is the proportion of energy supplied from feed to this stock class on this type of land that comes from imported supplementation, as opposed to homegrown feeds and pasture. Further, $\rho_{i}$ is the proportion of total annual MJ of ME per hectare grown that is eaten by stock class $i ; \gamma_{i}$ is the MJ of $\mathrm{ME}$ of feed energy produced per hectare per day (average) on the land where stock class $i$ is being run; $d_{i}$ is the number of days that animals of stock class $i$ are consuming feed grown from the hectarage used for this stock class; and $X_{i}$ is an indicator variable that takes a value of 1 if stock class $i$ should be considered in the definition of land area over which the methane emissions is attributed to, and otherwise takes a value of 0 . Variables $n_{i}, F_{i}$, and $\pi_{i}$ are functions of genetic traits. Therefore, the $\mathrm{CO}_{2}$-eq emissions per hectare $(\boldsymbol{E} \boldsymbol{H})$ can be expressed as follows:

$$
E H=\frac{E}{H}=\frac{\sum_{i=1}^{c} n_{i} F_{i} \alpha_{i} Y_{i}}{\sum_{i=1}^{c} n_{i} F_{i} \pi_{i} \frac{\rho_{i}}{\gamma_{i} d_{i}} X_{i}} .
$$

Table 3. Trait-specific estimated effects on feed intake per stock class per breeding cow, numbers of animals in the stock class per breeding cow,

\begin{tabular}{|c|c|c|c|c|c|c|}
\hline \multirow[b]{2}{*}{ Item } & \multicolumn{4}{|c|}{$\frac{d F(g)}{d g}^{1}$} & \multirow{2}{*}{$\frac{\frac{d n(g)}{d g}^{2}}{\text { Replacement }}$} & \multirow{2}{*}{$\frac{\frac{d \pi(g)}{d g}^{3}}{\text { Replacement }}$} \\
\hline & Replacement & $\begin{array}{l}\text { Cow wintered } \\
\text { off platform }\end{array}$ & $\begin{array}{l}\text { Cow wintered } \\
\text { on platform }\end{array}$ & $\begin{array}{l}\text { Cow on } \\
\text { platform }\end{array}$ & & \\
\hline Milk fat & & & & 69 & & $0 / 0.0006 / 0.001 / 0.002$ \\
\hline Milk protein & & & & 42 & & $0 / 0.0006 / 0.001 / 0.002$ \\
\hline Milk volume & & & & 1.44 & & \\
\hline Live weight & 55 & 5.47 & 5.47 & & & \\
\hline $\begin{array}{l}\text { Residual survival } \\
\text { SCS }\end{array}$ & & 0.024 & 0.024 & 0.96 & -0.00012 & \\
\hline Fertility & & & & 36 & -0.0034 & \\
\hline BCS & & -247 & -247 & 669 & & \\
\hline
\end{tabular}
and average feed energy produced per hectare per day per breeding cow

${ }^{1}$ Effect of trait change on feed intake energy (MJ of ME) per stock class per breeding cow per trait unit.

${ }^{2}$ Effect of trait change on number of animals per stock class per breeding cow per trait unit.

${ }^{3}$ Effect of trait change on proportion of feed supplies from the block of land where the stock class is being run (i.e., pasture and homegrown feeds). 
Stock classes partition the production system into different animal age and functional definitions and are further broken out in terms of the locations of the land used for farming each category of animals. Examples for the New Zealand dairy situation include milking cows managed on an area of land close to the milking shed (on the milking platform), dry cows wintered outside on a different property, often using consumption of in situ crops, and replacement females reared off the milking platform.

The change in $\mathrm{CO}_{2}$-eq per hectare due to a genetic change is denoted as emissions value $\left(\boldsymbol{E} \boldsymbol{V}^{h}\right)$ and is the first derivative of $E H$ with respect to a change in any genetic trait $g$ :

$E V^{h}=\frac{d E H(g)}{d g}$

$=\frac{1}{H}\left\{\begin{array}{c}\sum_{i=1}^{c} \alpha_{i} Y_{i}\left[\frac{d n_{i}(g)}{d g} F_{i}+\frac{d F_{i}(g)}{d g} n_{i}\right] \\ -E H \sum_{i=1}^{c} \frac{\rho_{i} X_{i}}{\gamma_{i} d_{i}}\left[\frac{d n_{i}(g)}{d g} F_{i} \pi_{i}+\frac{d F_{i}(g)}{d g} n_{i} \pi_{i}+\frac{d \pi_{i}(g)}{d g} n_{i} F_{i}\right]\end{array}\right\}$,

where $\frac{d n_{i}(g)}{d g}$ is the change in the number of animals of stock class $i$ present per unit change in a genetic trait, $\frac{d F_{i}(g)}{d g}$ is the change in feed intake (in MJ of ME) of animals of stock class $i$ for a 1-unit change in a genetic trait, and $\frac{d \pi_{i}(g)}{d g}$ is the change in the proportion of feed supplied from the block of land per unit change in a genetic trait.

\section{Systematic Emissions per Hectare Before Genetic Change}

The total hectares required per breeding cow per year, $H$, is derived from the required energy for the total number of animals on a block of land divided by the units of feed energy grown from the block of land (Equation [3]). Table 2 contains the parameter values that contributed to the calculation of the total number of hectares required per cow. On-platform cows are fed with supplements sourced from off the milking platform to boost their milk production; therefore the proportion of pasture fed, $\pi_{i}$, was estimated to be 0.91 when averaged across New Zealand dairy farm systems. For all the pasture produced from the block of land that constitutes a milking platform, some is used for the lactation period, but for a proportion of farms that winter their cows on platform, some of the total annual pasture production is used in the winter period; thus $\rho_{i}$ is introduced to account for this proportion. An indirect but convenient way to obtain $\rho_{i}$ is to extract the information from the energy requirement for corresponding stock classes. In the current study, the $\rho_{i}$ value for cows wintered on platform was calculated as $n_{\text {cow wintered on platform }} \times F_{\text {cow wintered on platform } /}$ ( $n_{\text {cow wintered on platform }} \times F_{\text {cow wintered on platform }}+n_{\text {cow on platform }}$ $\left.\times F_{\text {cow on platform }}\right)$, the proportion of these cows' feed intake energy over the feed intake energy for all stock classes that were on platform. Similarly, the $\rho_{i}$ value for cows on platform was calculated as $n_{\text {cow wintered on platform }}$ $\times F_{\text {cow on platform }} /\left(n_{\text {cow wintered on platform }} \times F_{\text {cow on platform }}+\right.$ $\left.n_{\text {cow wintered off platform }} \times F_{\text {cow wintered off platform }}\right)$, the proportion of their feed intake energy over the feed intake energy for all stock classes that were cows. The unit energy produced per hectare per day, $\gamma_{i}$, was assumed to be $345 \mathrm{MJ}$ of ME for a replacement, $506 \mathrm{MJ}$ of ME for a cow off the milking platform, and 371 for a cow on the milking platform (results not shown). In New Zealand, the number of days that animals of stock class $i$ are consuming feed grown from the hectarage used for this stock class, $d_{i}$, for a replacement is $690 \mathrm{~d}$, that for wintered cows per year is $60 \mathrm{~d}$, and that for on-platform cows per year is $305 \mathrm{~d}$.

\section{Changes in Proportion of Feed Supplied}

For our initial calculations, we assumed that changes in the proportion of feed supplied from the home block of land, as opposed to feed purchased from outside sources, with respect to a genetic change in each trait $g, \frac{d \pi(g)}{d g}$, were 0 for all traits. Relaxation of this assumption with changes in milk yield traits is tested later in the sensitivity analysis (Table 3 ).

\section{Models for Methane Intensity on an Animal Product Basis}

Total emissions per cow (Equation [1]) can also be expressed as a ratio of the total number of product output equivalents per cow. Milk protein is used here as the animal product standard, and other product outputs are converted to milk protein-eq using a revenue ratio. Equation [6] calculates the amount of animal product, expressed as milk protein-eq, produced per breeding cow across all products $(p)$ included in the pollution reduction objective definition, before genetic change $(M)$ :

$$
M=\sum_{j=1}^{p} k_{j} \sum_{i=1}^{c} n_{i j} m_{i j} X_{i j}
$$


where $n_{i j}$ is specific to both stock class and product type, thus different from $n_{i}$ in Equations [1-5]; $m_{i j}$ is the animal product outputs as milk protein-eq per animal in product $j ; k_{j}$ is the proportionality coefficient that converts product $j$ into milk protein-eq. Variables $m_{i j}$ and $k_{j}$ are functions of genetic traits; $X_{i j}$ is an indicator variable that takes a value of 1 if animal product type $j$ from stock class $i$ should be considered in the definition of outputted protein equivalents relative to which methane emissions are attributed to, and otherwise takes a value of 0 . Therefore, the emissions intensity per animal product $(\boldsymbol{E I})$ is

$$
E I=\frac{E}{M}=\frac{\sum_{i=1}^{c} n_{i} F_{i} \alpha_{i} Y_{i}}{\sum_{j=1}^{p} k_{j} \sum_{i=1}^{c} n_{i j} m_{i j} X_{i j}},
$$

and the emissions value $\left(\boldsymbol{E} \boldsymbol{V}^{m}\right)$ on a milk protein-eq intensity basis, following Amer et al. (2018), is the first derivative of $E I$ :

$$
\begin{aligned}
& E V^{m}=\frac{d E I(g)}{d g} \\
& =\frac{1}{M}\left\{\begin{array}{c}
\sum_{i=1}^{c} \alpha_{i} Y_{i}\left[\frac{d n_{i}(g)}{d g} F_{i}+\frac{d F_{i}(g)}{d g} n_{i}\right] \\
-E I \sum_{j=1}^{p} k_{j} \sum_{i=1}^{c} X_{i j}\left[\frac{d n_{i j}(g)}{d g} m_{i j}+\frac{d m_{i j}(g)}{d g} n_{i j}\right]
\end{array}\right],
\end{aligned}
$$

where $\frac{d m_{i j}(g)}{d g}$ is the change in the animal product $j$ per unit change in a genetic trait for stock class $i$.

\section{System Emissions Intensity Before Genetic Change}

Our model assumed that the breeding cow is the only stock class that produces the 4 types of products under consideration - that is, milk fat, milk protein, milk volume, and meat (live weight) - and $n$ is 1 for all types of products. The revenue to dairy farmers in New Zealand from surplus calves is typically negligible. The $m$ as $m_{i j}$, indicating the animal product (milk fat, milk protein, milk volume, liveweight) outputs for milk fat, protein, and volume, came directly from the NBO. The $m$ for live weight was calculated from average cow live weight of $450 \mathrm{~kg}$, multiplied by $95 \%$ of cows that reach slaughter and $22 \%$ of which are culled each year. The conversion coefficient $(k)$ was obtained from the ratio of the revenue of each product and milk protein: the 5-year averages adjusted to 2019 equivalents using the consumer price index were used for milk fat, protein, and volume revenues, which were $\mathrm{NZ} \$ 5.79,6.07$, and $-0.04 / \mathrm{kg}$ (at time of writing, NZ $\$ 1=\mathrm{US} \$ 0.65$; Jeremy Bryant, DairyNZ, Hamilton, New Zealand, personal communication), respectively. Milk volume revenue is negative because it accounts for the cost of shipping and processing milk volume. The live weight revenue came from the meat price estimate of $\mathrm{NZ} \$ 4.08 / \mathrm{kg}$ of cow weight multiplied by $44 \%$, as the dressing-out percentage of the live weight.

\section{Changes in Animal Products as Milk Protein Equivalents}

The change of product due to a 1-unit change in each genetic trait $\left[\frac{d m(g)}{d g}\right]$ is described in Table 4 . The breeding cow was assumed to be the only stock class that produces milk and meat, with all other products generated through the sale of surplus calves and replacement heifers excluded from the intensity calculations.

Changes in milk component traits (milk fat, milk protein, and milk volume) affect only their corresponding products at a 1:1 ratio. Changes in live weight affects only the live weight product, meat. The percentage of cows culled per breeding cow was assumed to be the same as the replacement rate, that is, $22 \%$. Out of these, we assumed that $5 \%$ died without their meat going to the market. Therefore, a 1-kg increase in live weight led to a $0.21-\mathrm{kg}$ increase in live weight product.

Survival determines the age structure of the herd, thus influencing all 4 product types. We have modeled a base herd and an improved-survival herd. In the improved-survival herd, we have assumed that survival to each of the next successive lactations improves by $1 \%$. Cows in this improved-survival herd require 0.007 fewer replacements per breeding cow in the herd, leading to an equivalent reduction in culled breeding cows in the herd, but this is for a herd with $57.14 \mathrm{~d}$ longer average survival. Therefore, the reduction in the number of cull cows is $0.007 / 57.14 \mathrm{~d}=0.00012$ per day of additional survival. The extra day of lifespan also means more mature, higher-producing cows in the herd, such that the herd produces $0.024 \mathrm{~kg}$ more milk solids per cow on average. Based on the milk composition of New Zealand dairy cows, each kilogram of milk solid results in $0.55,0.45$, and $11.52 \mathrm{~kg}$ of milk fat, protein, and volume, respectively. Thus $0.024 \mathrm{~kg}$ of additional milk solid per extra day of survival converts to 0.0087 , 0.0070 , and 0.18 additional $\mathrm{kg}$ of milk fat, protein, and volume. Increasing fertility by $1 \%$ leads to cows living an average of $57.14 \mathrm{~d}$ longer and $0.7 \%$ fewer replacements - which is to say, $0.7 \%$ fewer culled cows. This translates to $0.01 \%$ fewer culled cows per day. Using 
this number multiplied by the average cow live weight of $450 \mathrm{~kg}, 95 \%$ slaughter rate, and $22 \%$ cull rate, the $1 \%$ increase in survival led to a $0.053-\mathrm{kg}$ reduction in live weight product.

Somatic cell score has negative effects on milk components through discarded milk and reduced survival days. The reductions in milk fat, protein, and volume were taken as $0.24,0.19$, and $4.94 \mathrm{~kg}$, corresponding to 1 score increase in SCS, and the reduction in survival days was estimated as $65.13 \mathrm{~d}$ as a genetic regression of survival on SCS (NZAEL, 2013). The change in milk components from increasing 1 SCS score was obtained using $65.13 \mathrm{~d}$, as previously, multiplied by the change to milk components associated with change in survival, as in the preceding paragraph, plus an additional adjustment for discarded milk from cows treated with antibiotics.

Improved fertility increases milk production directly, through longer lactations for earlier-calving cows, and indirectly because it improves survival, changing the age structure of the herd so that a higher proportion of the herd is mature cows at full milk production. Based on calculations used for the NBO economic values, a $1 \%$ improvement in fertility directly results in $0.69 \mathrm{~kg}$ of extra milk solids, which equates to $0.39,0.31$, and $7.99 \mathrm{~kg}$ of extra milk fat, protein, and volume, respectively. The indirect effect of fertility on milk production through improved survival was calculated similarly as in the earlier paragraph. The effect of fertility on live weight occurs through an indirect effect of higher survival rate. Therefore, $27.85 \mathrm{~d}$ multiplied by the survival influence on live weight led to a reduction of $1.5 \mathrm{~kg}$ of live weight product with a $1 \%$ increase in fertility.

Body condition score affects milk component production through extended lactation, as many farmers in New Zealand stop milking cows of low BCS earlier in the autumn so that they have time to recover condition while autumn pasture feed is still available. We assumed that $40 \%$ of cows had lactation prolonged by an average of $34 \mathrm{~d}$ and, for each day, produced $1 \mathrm{~kg}$ more milk solids. After accounting for typical milk composition, the increase of milk production through an increase of 1 BCS was estimated as $7.9 \mathrm{~kg}$ of milk fat, $6.3 \mathrm{~kg}$ of milk protein, and $162 \mathrm{~kg}$ of milk volume.

\section{Changes in Stocking Rate by Stock Class, Product Type, and Breeding Trait}

For live weight product, the change in stocking rate of replacement heifers was the same as described in previous sections. Other traits of breeding cows and milk products do not influence replacement rate; consequently, the change of replacement rate coefficient for these traits is 0 . Breeding cow and offspring stock classes were ignored, because none of the trait changes influence the number of cows or offspring (Table 4).

\section{Response to Index Selection}

Genetic trends averaged over the past 5 years were accessed from NZAEL (Melissa Stephen, NZAEL, Hamilton, New Zealand, personal communication).

Table 4. Trait-specific estimated effects on animal product per stock class per breeding cow and numbers of animals in the stock class per breeding cow producing the animal product

\begin{tabular}{|c|c|c|c|c|c|}
\hline Parameter & Trait & $\begin{array}{l}\text { Milk fat } \\
\quad(\mathrm{kg})\end{array}$ & $\begin{array}{l}\text { Milk protein } \\
(\mathrm{kg})\end{array}$ & $\begin{array}{l}\text { Milk volume } \\
\text { (L) }\end{array}$ & $\begin{array}{l}\text { Live weight } \\
(\mathrm{kg})\end{array}$ \\
\hline \multirow{8}{*}{$\frac{d m(g)}{d g}^{1}$} & Milk fat & 1 & - & - & - \\
\hline & Milk protein & - & 1 & - & - \\
\hline & Milk volume & - & - & 1 & - \\
\hline & Live weight & - & - & - & 0.21 \\
\hline & Residual survival & 0.0087 & 0.0070 & 0.18 & -0.053 \\
\hline & SCS & -0.81 & -0.65 & -17 & - \\
\hline & Fertility & 0.63 & 0.51 & 13 & -1.47 \\
\hline & BCS & 7.85 & 6.33 & 162 & — \\
\hline \multirow{8}{*}{$\frac{d n(g)^{2}}{d g}$} & Milk fat & - & - & - & - \\
\hline & Milk protein & - & - & - & - \\
\hline & Milk volume & - & - & - & - \\
\hline & Live weight & - & - & - & - \\
\hline & Residual survival & - & - & - & -0.00012 \\
\hline & SCS & - & - & - & - \\
\hline & Fertility & - & - & - & -0.0034 \\
\hline & BCS & - & - & - & - \\
\hline
\end{tabular}

${ }^{1}$ Effect of trait change on animal product output per stock class per breeding cow per trait unit. This affects only the cow on platform stock class.

${ }^{2}$ Effect of trait change on number of animals per stock class per breeding cow producing the animal product. This affects only the replacement heifer stock class. 
Trait-wise annual responses in $E, E H$, and $E I$ from index selection were calculated as follows, as an aggregation of annual change of all traits, following Harville and Henderson (1967):

$$
\Delta E^{X}=\sum_{i=1}^{t} X_{i} \Delta G_{i},
$$

where $X$ could be $G V, E V^{h}$, or $E V^{m}$, and $\Delta G$ is the annual rate of genetic change in genetic merit, each for the $i$ th trait. The percentage change in methane emitted due to 1 year of genetic progress is calculated as $100 \frac{\Delta E^{X}}{\bar{X}} \%$, where $\bar{X}$ could be the mean values before genetic change of either $E, E H$, or EI. Further, the total change in the amount of methane emissions nationally per year was calculated as $\Delta E^{E V^{h}}$ multiplied by the total effective hectares used for dairy production in New Zealand.

The current genetic trend of breeding traits was obtained from NZEAL, for an evaluation run on Aug. 13, 2018 (Table 5). The average breeding values from 2013 to 2017 were used to form a simple linear regression for each trait on year of birth, and the regression coefficients were used as genetic trends.

\section{Sensitivity Analysis}

The effects of changing both the rate of supplementary feeding as milk production increases and the value component ratio (VCR: the market price of milk fat relative to milk protein) on $E V$ values for milk protein and fat were tested. For supplementation, we tested the change in $E V^{h}$ under scenarios where the proportion of supplementary feeds (50,100, and 200\%) included in feed intake associated with trait changes was increased proportionally relative to the current proportion of the diet fed as supplements, so as to offset the additional feed requirements associated with the trait change. For VCR, we tested the change of $E V^{m}$ under scenarios when the ratio of milk fat market price to milk protein market price was at $0.55,0.95$, and 1.35 , thus affecting the definition of milk protein equivalents, which are based on product values relative to the farmer revenue from increased or decreased protein production.

\section{Sensitivity to Effects of Supplementation on Methane Emissions}

The change in genetic traits influence $\frac{d \pi_{i}(g)}{d g}$ in an indirect way. It was assumed that when selection for milk component traits (fat and protein) resulted in si-
Table 5. Average annual genetic trend for New Zealand National Breeding Objective traits from year 2013 to 2017

\begin{tabular}{llc}
\hline Trait & Unit & Genetic trend \\
\hline Milk fat & $\mathrm{kg}$ & 1.14 \\
Milk protein & $\mathrm{kg}$ & 1.18 \\
Milk volume & $\mathrm{L}$ & 27 \\
Live weight & $\mathrm{kg}$ & 1.23 \\
Residual survival & day & -0.52 \\
SCS & Score & -0.02 \\
Fertility & \% & 0.32 \\
BCS & Score & 0.01 \\
\hline
\end{tabular}

multaneous 1-kg increases in breeding values of these traits, that farmers would respond in one of two ways to meet increasing feed demands: (1) Decreasing stocking rate (if possible) or (2) increasing supplementation (imported feed). Each of these outcomes would have different effects on the amount of emissions from the farm, with increased supplementation through feed sources grown off the main farm area highly likely to result in increased methane emissions per hectare of milking platform area that describes the magnitude of the dairy industry.

A sensitivity test is needed to evaluate the effect on trait emissions value, $E V^{h}$, when supplementation was assumed to increase as a direct result of genetic progress in milk fat and protein - or, rather, the change (reduction) in the proportion of feed supplied from the block of land that the animal is being run on (Table 3). Four values were modeled to reflect where extra feed would come from to meet increased feed requirements due to a 1-unit increase in either milk fat or protein: (1) platform-grown feed (i.e., no imported feed, just a decrease in stocking rate), (2) half from platform-grown feed and half from imported feed, (3) all from imported feed, or (4) all from imported feed, with imported feed displacing some of the platform-grown feed.

In the base model, it was assumed that 0.91 of the feed requirements of cows on platform come from platform-grown feed (Table 2). Further, we simplify the derivation by considering feed requirements in terms of relativities of the total requirements for milk production, through which a constant $c$ (which conveniently factors out of our calculations) can be converted to MJ of ME. Thus, total feed required $(F T)$ for lactation at base genetic merit is

$$
F T=c \times A M S \times 1.7,
$$

where $A M S$ is the average annual milk solids yield per cow, $c$ converts $A M S$ into energy requirement for milk yield, and 1.7 scales up milk solids energy requirements to total energy requirements, because maintenance energy requirements for a lactating cow are about $70 \%$ 
of its energy requirements for milk production. The proportion of FT met from homegrown feed is 0.91 for our base cow genotype.

Working with the above principle, and cancelling out $c$ from the equation, the change in the proportion of feed sourced from the milking platform when milk solids production per cow is increased by $1 \mathrm{~kg}$ is calculated as

$$
\begin{aligned}
& \Delta F T=\frac{\pi \times c \times A M S \times 1.7}{c \times A M S \times 1.7+c \times 1 \times q}-\frac{\pi \times c \times A M S \times 1.7}{c \times A M S \times 1.7} \\
& =\frac{-\pi \times q}{A M S \times 1.7+q}
\end{aligned}
$$

where $q$ is the proportion of additional feed required by cows genetically producing higher milk solids that is fed as supplement sourced from off the milking platform. We assumed $q$ values of 0 (higher milk solids genetic potential fully accounted for by a reduction in stocking rate, in which case $\frac{d \pi_{i}(g)}{d g}=0$ for milk fat and milk protein), $50 \%$ (half of extra feed from supplementation), $100 \%$ (all extra feed from supplementation), and $200 \%$, where the assumption is that farmers more than compensate for the extra feed requirements with additional supplementation. The rationale for testing a value of $q$ greater than 1 is that higher milk yield potential leads to cows with stronger appetites, which in turn allows farmers to feed more supplementation in the milking shed, while still maintaining optimal postgrazing pasture residuals, which are important for future DM yield from the grazed area.

In an example of $A M S$ equal to $330 \mathrm{~kg}$, if the increase in feed requirements due to a 1-unit increase in either milk fat or protein is fully met through supplementary feeding, then the reduction in total feed requirements as the proportion of pasture coming from the platform is -0.00162 from Equation [11]. That is, where cows on platform usually receive 0.91 of their feed requirements from platform-grown feed, they now receive $0.91-0.00162=0.9038$ from platform-grown feed and 0.00162 from imported feed.

\section{Application to Traits in the New Zealand National Breeding Objective}

The equations above were applied to the 8 traits currently included in the New Zealand national selection index. Equations [1-7] were parameterized assuming 4 animal classes $(c=4)$ : replacement heifers (from birth to first calving), cows wintered off the milking platform, cows wintered on the milking platform, and cows on the milking platform for seasons other than winter, as these classes have different feeding systems and energy requirements. For example, from 35 d before lactation until the end of lactation from August to April, cows are typically on farmland within walking distance of the milking facility - that is, the milking platform. Their feed comes predominantly from pasture, with some supplementation with forage and concentrates. From May to July in winter, dry cows are either off the platform and being fed standing crops or on the platform eating pasture (in regions where winter pasture growth is sufficient) or else crops grown on the home farm for winter feeding. Replacement heifers consume only pasture (perhaps with some forage crop or conserved forage fed during winter) until their first calving.

\section{RESULTS}

\section{Coefficients Calculation}

The conversion factor $\alpha_{i}$ for replacement, cow wintered off platform, cow wintered on platform, and cow on platform stock classes, was estimated as 0.056, 0.050, 0.052 , and $0.052 \mathrm{~kg}$ of $\mathrm{CO}_{2}$-eq/MJ of $\mathrm{ME}$, respectively (Table 2). The $\mathrm{CO}_{2}$-eq emitted by an average breeding cow annually was estimated as $3,087 \mathrm{~kg}$ in total.

\section{Effects of Index Traits on System Gross Emissions}

The gross emissions, $E$, before genetic change was estimated as $3,087 \mathrm{~kg}$ of $\mathrm{CO}_{2}$-eq/breeding cow per year (Table 2), of which the breeding cow itself accounted for $2,313 \mathrm{~kg}$ during lactation and $253 \mathrm{~kg}$ during winter. Replacements for each breeding cow accounted for 522 $\mathrm{kg}$.

\section{Changes in Feed Intake by Stock Class and Breeding Trait}

The changes in feed intake, $\frac{d F(g)}{d g}$, for a 1-unit change in each of the traits are summarized in Table 3. The total energy based on a New Zealand heifer of average live weight was estimated to be $42,359 \mathrm{MJ}$ of ME, and this number increased by $55 \mathrm{MJ}$ of ME when the heifer had its live weight at first calving increased by $1 \mathrm{~kg}$. For wintered cows, both on and off platform, there was a reduction in energy requirements of $247 \mathrm{MJ}$ of $\mathrm{ME}$ based on a 1-unit increase in BCS. Cows on platform during other seasons had an estimate of $667 \mathrm{MJ}$ of ME on average. 


\section{Changes in Stocking Rate by Stock Class and Breeding Trait}

The change in number of replacements required was estimated as -0.00012 for residual survival and -0.0034 for fertility traits, respectively (Table 3 ). For other traits it was estimated as 0 .

\section{Changes in Gross Emissions (per Cow)}

Changes in gross methane emissions output per cow $(G V)$ for a 1-unit change in each of the traits are shown in Table 6. In general, increasing production traits and BCS corresponded to increases in gross per-cow methane emissions, whereas increasing survival and fertility corresponded to decreases in gross per-cow methane emissions. Somatic cell score did not affect gross methane emissions. Body condition score has a very high impact on the emissions change $(22 \mathrm{~kg} /$ cow per year).

\section{Effects of Index Traits on System Emissions per Hectare}

The emissions per hectare, $E H$, before genetic change was estimated as $6,915 \mathrm{~kg}$ of $\mathrm{CO}_{2}$-eq/ha per year (Table $2)$. We derived the changes in emissions per ha, $E V^{h}$ (Table 6). As for the pattern of changes in gross methane emissions, genetic improvements in survival and fertility were estimated to reduce the methane intensity per hectare, whereas other traits were estimated to increase methane intensity per hectare. Somatic cell score did not influence the change in methane emissions per hectare.

\section{Effects of Index Traits on System Emissions Intensity}

The parameters and total animal products as milk protein-eq before genetic change are listed in Table 7 . The annual production, $m$, for milk fat, milk protein, milk volume, and live weight were estimated as $188 \mathrm{~kg}$, $151 \mathrm{~kg}, 3,897 \mathrm{~L}$, and $94 \mathrm{~kg}$, respectively. The total product outputs by a breeding cow per year before genetic change, $M$, was estimated as $333 \mathrm{~kg}$ of milk protein-eq, and the emissions intensity, EI, was estimated as 9.27 $\mathrm{kg}$ of $\mathrm{CO}_{2}$-eq/ $\mathrm{kg}$ of milk protein-eq.

\section{Changes in Emissions Intensity on a Milk Protein Equivalents Basis}

The changes in emissions intensity - that is, emissions values, $E V^{m}$ - by trait are listed in Table 3. Milk fat, milk protein, survival, fertility, and BCS had negative (favorable) emissions intensity values because in-
Table 6. Trait-specific estimated effects of 1-unit trait change on gross methane emissions [ $\mathrm{kg}$ of $\mathrm{CO}_{2}$-equivalent (eq) emissions/breeding cow per year, $G V]$, changes in emissions per hectare $\left(\mathrm{kg}\right.$ of $\mathrm{CO}_{2}$-eq emissions/ha, $\left.E V^{h}\right)$, and changes in emissions intensity $\left(\mathrm{kg}\right.$ of $\mathrm{CO}_{2}$-eq emissions $/ \mathrm{kg}$ of milk protein-eq, $E V^{m}$ )

\begin{tabular}{llccc}
\hline Trait & Unit & $G V$ & $E V^{h}$ & $E V^{m}$ \\
\hline Milk fat & $\mathrm{kg}$ & 3.57 & 0.04 & -0.02 \\
Milk protein & $\mathrm{kg}$ & 2.19 & 0.02 & -0.02 \\
Milk volume & $\mathrm{L}$ & 0.07 & 0.001 & 0.00004 \\
Live weight & $\mathrm{kg}$ & 2.40 & 0.12 & 0.005 \\
Residual survival & day & -0.24 & -0.32 & -0.0007 \\
SCS & Score & 0 & 0 & 0.04 \\
Fertility & $\%$ & -6.28 & -8.80 & -0.04 \\
BCS & Score & 22 & 26 & -0.29 \\
\hline
\end{tabular}

creasing 1 unit of these traits generated proportionally more products than methane. High SCS results in lost milk output through discarded milk, with no effect on methane, so SCS had a small positive (unfavorable) emissions intensity value.

\section{Methane Emissions Response to Index Selection}

The gross emission, $E$, will increase by $9.95 \mathrm{~kg} /$ breeding cow in 2020 ( $0.37 \%$ increase relative to 2019$)$, $E H$ will remain relatively unchanged with just a $0.03 \%$ reduction $(-2.31 \mathrm{~kg})$, whereas $E I$ will reduce by $0.04 \mathrm{~kg}$ $(-0.43 \%$; Table 8$)$.

\section{Sensitivity to Effects of Supplementation on Methane Emissions}

The changes in kilograms of $\mathrm{CO}_{2}$-eq emissions per hectare under scenarios when the proportion of supplementation is $0,50,100$, or $200 \%(100 \%+$ additional pasture substituted by supplementation) of total feed intake is shown in Figure 1. The average annual milk solids was estimated as $330 \mathrm{~kg}$, as the summation of milk protein and fat. Correspondingly, the change in feed supplied from the block of land $\left(\frac{d \pi_{i}(g)}{d g}\right)$ for both

Table 7. Animal product-specific parameters calculating animal product output per milk protein equivalent per breeding cow $(M)$ and $\mathrm{CO}_{2}$-eq per milk protein equivalent $(E I)$ before genetic change

\begin{tabular}{lccccc}
\hline Parameter & $\begin{array}{c}\text { Milk } \\
\text { fat }\end{array}$ & $\begin{array}{c}\text { Milk } \\
\text { protein }\end{array}$ & $\begin{array}{c}\text { Milk } \\
\text { volume }\end{array}$ & $\begin{array}{c}\text { Live } \\
\text { weight }\end{array}$ & Total \\
\hline$k^{1}$ & 0.95 & 1 & -0.01 & 0.3 & \\
$m^{2}$ & 188 & 151 & 3,897 & 94 & 333 \\
$M$ & 179 & 151 & -25 & 28 & 9.27 \\
$E I^{m}$ & - & - & - & - & - \\
\hline
\end{tabular}

${ }^{1}$ Conversion coefficient converting animal product to milk protein equivalent.

${ }^{2}$ Animal product output per breeding cow. 
milk fat and milk protein change from 0 to -0.0006 , -0.001 , and -0.003 , respectively. Consequently, the milk fat-related annual emissions change will increase from $-0.04 \mathrm{~kg}$ at no supplement to $21 \mathrm{~kg}$ at $200 \%$ proportion of supplement scenario. Similarly, the milk protein-related annual emissions change will increase from -0.03 to $22 \mathrm{~kg}$. By contrast, the total emissions of all other traits remains at $-2.24 \mathrm{~kg}$. Adding up all traits, the changes of emissions per milking platform hectare will increase rather than reduce when high genetic merit cows are fed more supplements, with the highest value of $41 \mathrm{~kg}$ under the $200 \%$ of additional energy from supplement scenario, equal to $0.59 \%$ of the emissions in 2019.

\section{Sensitivity to Effects of Value Component Ratio on Methane Emissions}

The genetic trends in expected emissions intensity in response to VCR changes is shown in Figure 2. The VCR affects both the base value of $E I$ before genetic changes and genetic trend of emissions per unit of milk protein equivalent. The EI under VCR of $0.55,0.95$, and 1.35 were estimated as $11.95,9.27$, and $7.57 \mathrm{~kg}$ of $\mathrm{CO}_{2}$-eq $/ \mathrm{kg}$ of milk protein-eq-reduced emissions intensity along with higher VCR. The percentage of emissions per unit of milk protein equivalent compared with EI in 2019 shrank only by $0.002 \%$ when VCR increased from 0.55 to 1.35 .

\section{DISCUSSION}

\section{Methane Emissions Response to Index Selection}

We estimated the $E$ (gross $\mathrm{CO}_{2}$-eq emissions per breeding cow per year) to be $3,087 \mathrm{~kg}$, equal to $338 \mathrm{~g}$ of methane/cow per day. Given the DairyNZ statistics in the year 2017 , there were 4.8 million dairy cattle in total across the country, resulting in an annual methane estimate of $15 \mathrm{Mt}$ of $\mathrm{CO}_{2}$-eq, which is fully concordant with the $14 \mathrm{Mt}$ reported by DairyNZ for 2014 (methane contributed to approximately $70 \%$ of the total emissions of $20 \mathrm{Mt}$ from methane and nitrous oxide), and similar to the $18 \mathrm{Mt}$ reported by the New Zealand Production Commission (2018). This is also similar to

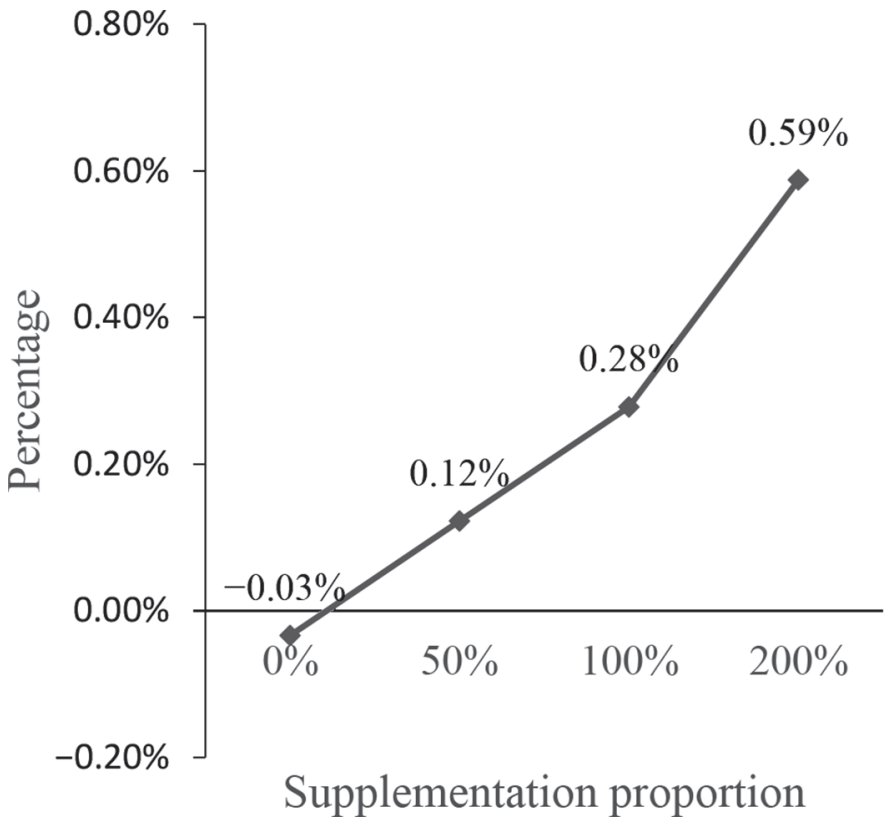

Figure 1. Changes of emissions per hectare $\left[\mathrm{kg}\right.$ of $\mathrm{CO}_{2}$ equivalent (eq) emissions/ha, $\left.E V^{h}\right]$ as a percentage of emissions per hectare in 2019, under different supplementation proportions.

the Bell et al. (2013) estimate of $322 \mathrm{~g} / \mathrm{cow}$ per day. The milk protein, milk fat, milk volume, live weight, and SCC $E V^{m}$ estimates all have the same direction as those in Bell et al. (2013). The absolute values are not comparable, because they used per-lactation traits and per unit of milk solids for their definition of intensity.

In the genetic trend of $G V$, milk fat had the largest contribution of $4.07 \mathrm{~kg}$ of $\mathrm{CO}_{2}$-eq, accounting for $41 \%$ of the contribution by all traits. This contribution was followed in magnitude by $2.96 \mathrm{~kg}$ of $\mathrm{CO}_{2}$-eq from live weight, $2.60 \mathrm{~kg}$ of $\mathrm{CO}_{2}$-eq from milk protein, and $1.98 \mathrm{~kg}$ of $\mathrm{CO}_{2}$-eq from milk volume. The fitness traits contributed far less than production traits, and fertility contribution was a reduction of $1.99 \mathrm{~kg}$ of $\mathrm{CO}_{2}$-eq. Body condition score has an apparently very high impact on the emissions change (22 $\mathrm{kg}$ of $\mathrm{CO}_{2}$-eq/cow per year), but it would take many years of selection to achieve a unit change. Richardson et al. (2019) estimated a 55-g methane reduction/cow per lifetime associated with 1-unit increase of adjusted feed efficiency in Canadian

Table 8. Changes of genetic trend prediction of gross $\mathrm{CO}_{2}$-equivalent emissions $\left(\mathrm{kg}\right.$ of $\mathrm{CO}_{2}$-eq/cow per year, E), emissions per hectare ( $\mathrm{kg}$ of $\mathrm{CO}_{2}$-eq/ha, $\left.E H\right)$, and emissions intensity ( $\mathrm{kg}$ of $\mathrm{CO}_{2}$-eq $/ \mathrm{kg}$ of milk protein-eq, $E I$ )

\begin{tabular}{|c|c|c|c|c|c|}
\hline Parameter & $\begin{array}{c}\text { Total value at } 2019 \\
(\mathrm{~kg})\end{array}$ & $\begin{array}{l}\text { Annual change } \\
(\mathrm{kg})\end{array}$ & $\begin{array}{c}\text { Annual change } \\
(\%)^{1}\end{array}$ & $\begin{array}{l}\text { 20-year change } \\
(\mathrm{kg})\end{array}$ & $\begin{array}{c}\text { 20-year change } \\
(\%)^{1}\end{array}$ \\
\hline$E$ & 3,087 & 10 & 0.32 & 199 & 6.45 \\
\hline$E H$ & 6,915 & -2.31 & -0.03 & -46 & -0.67 \\
\hline
\end{tabular}

${ }^{1}$ Percentage compared with 2019. 


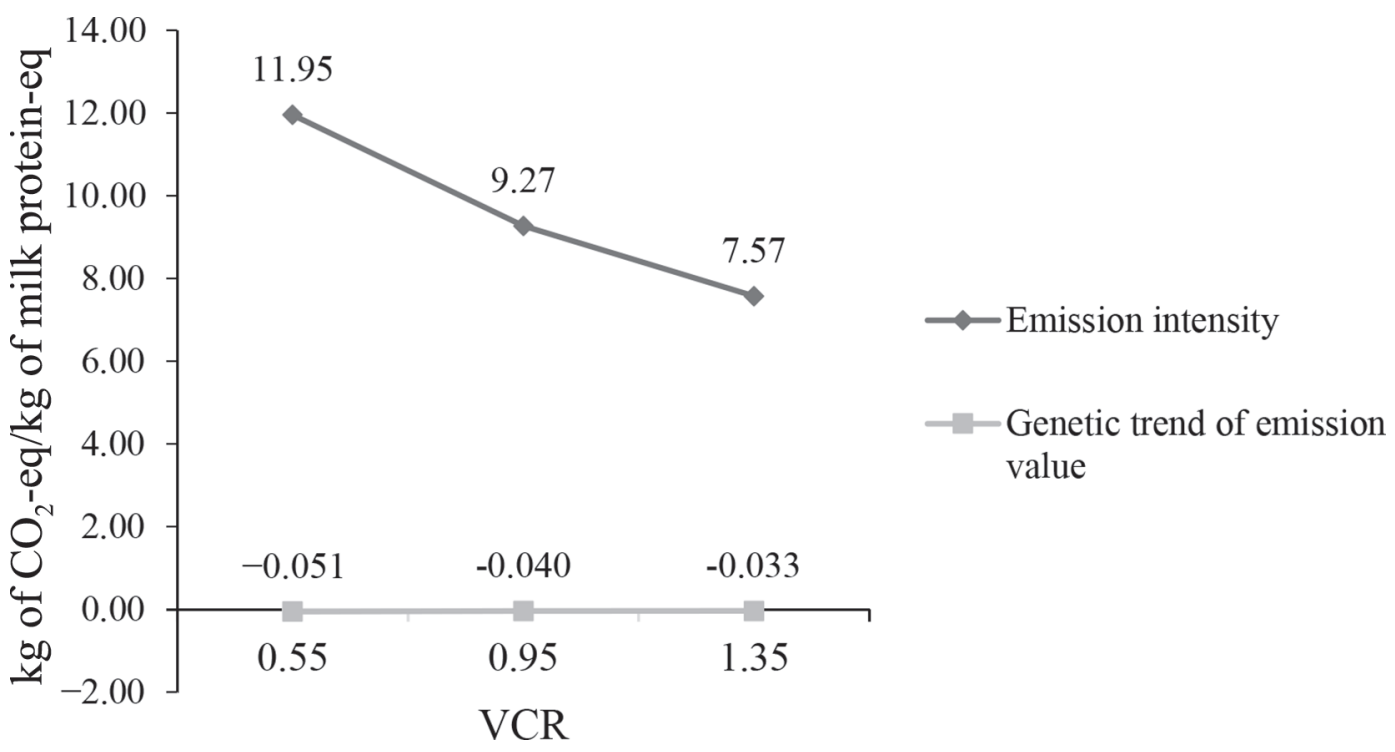

Figure 2. Emissions intensity before genetic change $\left[\mathrm{kg}\right.$ of $\mathrm{CO}_{2}$ equivalent (eq) emissions $/ \mathrm{kg}$ of milk protein-eq] and annual genetic change of emissions value ( $\mathrm{kg}$ of $\mathrm{CO}_{2}$-eq emissions $/ \mathrm{kg}$ of milk protein-eq per year) under different value component ratios (VCR).

dairy cows, equivalent to $1.38 \mathrm{~kg}$ of $\mathrm{CO}_{2}$-eq, implying the possibility of selecting animals directly based on feed efficiency to reduce methane emissions.

The $E V^{m}$ is a more informative measurement of the effect of genetic improvement of dairy cattle compared with $G V$. This is a system-wide methane intensity that reflects animal production efficiency. It considers both improved feed utilization of individual animals and improved total system efficiency. In contrast, using reduction in gross emissions as the only specified target can encourage decreasing the per-animal production outputs and, consequently, decrease efficiency of production, which is highly counterintuitive (Quinton et al., 2018).

The negative trend of $0.43 \%$ reduction in emissions intensity per annum across all traits indicates that the current breeding scheme is already working toward breeding more efficient animals. For any given level of consumer demand for dairy farm outputs, the number of dairy cows required is decreasing over time because of their higher production efficiency, and so methane emissions will also decline. Our results are consistent with those of Kandel (2018), who found negative genetic correlations between log-transformed methane emissions intensity and protein yield $(-0.4)$ and fat yield $(-0.15)$ in Holstein cattle in Belgium. Similarly, Richardson (2018) estimated 1\% annual reduction in emissions intensity for Canadian dairy cows.

Similarly, $E V^{h}$ considers the utilization of pasture at farm-management level, which is important to New Zealand farmers. In the formula components, the re- duction in number of replacements caused by improved fertility reduced the energy intake associated with rearing replacements. Correspondingly, $\mathrm{CO}_{2}$-eq emissions reduced considerably $(-2.79 \mathrm{~kg})$, and this balanced out the increase in emissions per hectare per annum contributed by the remaining traits in the NBO $0.48 \mathrm{~kg}$. Thus the total emissions per hectare per annum by all traits was $-2.31 \mathrm{~kg}$ of $\mathrm{CO}_{2}$-eq, a slightly favorable trend for greenhouse gas emissions per hectare under the base assumption of no change in supplementation rate due to genetic change in milk solids production potential.

\section{Effects of Feed Supplementation on Methane Emissions}

In the current model, where feed intake drives predicted methane emissions, feeding high-energy supplements correlates with high methane emissions. Therefore, by feeding breeding cows with supplementation to fully meet the genetic potential from gains in milk fat and milk protein, the methane emissions increase accordingly.

We considered an extreme case when the supplementation was doubled - even the pasture supply was substituted by high-concentration feed - and estimated that emissions per hectare from current annual trends would reverse in direction from $-2.31 \mathrm{~kg} /$ ha per year to $41 \mathrm{~kg} / \mathrm{ha}$ per year. Compared with the total emissions per hectare estimate of $6,915 \mathrm{~kg}$ in 2017 , this is a small number, but nationwide this would aggregate to $306 \mathrm{kt}$ more $\mathrm{CO}_{2}$-eq emissions/year. 


\section{Effects of Value Component Ratio on Methane Emission}

The relative market prices of milk components (i.e., milk protein and milk fat) change due to short-term supply and demand imbalances in milk product supply but also due to long-term changes in demands for milk products by consumers. In recent years the global price ratio of milk fat to milk protein (i.e., the VCR) has been increasing at a quite rapid rate, reflecting a worldwide shortage in products with a high proportion of milk fat. The surge in demand for milk fat follows a recent shift in nutritional recommendations as regards obesity risks of milk fat, leading to food manufacturers improving food product appeal through addition of milk fat, reducing added sugar for health benefits (Muehlhoff et al., 2013). The current VCR value used in industry payment has reached 1.3, whereas a few years ago it was around 0.5 (Jeremy Bryant, DairyNZ, Hamilton, New Zealand, personal communication). This influences the $\mathrm{CO}_{2}$-eq emissions intensity per milk protein-eq through the $k$ value in Equations [7] and [8] - that is, the milk protein-eq increases when $k$ increases while $E$ remains the same; hence, the $E I$ decreases. Our estimates showed that higher VCR leads to slightly smaller absolute emissions value reduction but slightly larger $E V^{m}$ reduction relative to the $E I$, because the $E I$ reduced more drastically. This reduction is a pure reflection of varying animal product unit used for emissions intensity but not a reduction in absolute methane emissions. Thus, changing the VCR changes the true magnitude of milk protein output equivalent units but not the overall trend in EI due to genetic change. Fat has a higher feed energy requirement per unit output in milk than does protein, and so genetic gains in fat yield result in less efficiency gains than genetic improvements in protein yields. However, if more weight is given to fat in the NBO, this may lead to more genetic gain in fat, because there is more genetic variation in milk fat yield than there is in milk protein yield.

\section{Future Estimates}

The current study shows that at this changing rate, in 20 years from now, the $\mathrm{CO}_{2}$-eq emissions for a breeding cow will increase by $199 \mathrm{~kg}$. The emissions per hectare will reduce by $46 \mathrm{~kg}$, and the emissions intensity per milk protein-eq will reduce by $800 \mathrm{~g}$ from $9.23 \mathrm{~kg}$ to $8.47 \mathrm{~kg}$. DairyNZ statistics for the year 2017 estimate a total population of 4.8 million dairy cattle across the country. If we assume that the number of dairy cattle will remain the same in 20 years, then the gross $\mathrm{CO}_{2}$-eq emissions from methane will increase by
$995 \mathrm{kt}$ by $2037(3,286 \mathrm{~kg} /$ cow $-3,087 \mathrm{~kg} /$ cow $\times 4.8$ million cows). This is unlikely, given increasing environmental restrictions on dairy farming. On the other hand, given the Beef + Lamb NZ Economic Service statistics, the land area used by the dairy sector was 2.4 Mha in 2017. If the land area remains the same, by 2037 total industry emissions will reduce by $111 \mathrm{kt}$ $(6,915 \mathrm{~kg} / \mathrm{ha}-6,869 \mathrm{~kg} / \mathrm{ha} \times 2.4 \mathrm{Mha})$. However, in 20 years' time if cows with higher genetic merit end up being fed proportionally more supplements than currently, the industry change on a fixed hectare-for-dairy basis could increase up to $1,949 \mathrm{kt}(7,727 \mathrm{~kg} / \mathrm{ha}-6,915$ $\mathrm{kg} / \mathrm{ha} \times 2.4 \mathrm{Mha})$, instead of a 111-kt reduction if the higher feed requirements of cows with high breeding worth result in a corresponding proportional reduction in cows per hecatre.

\section{Key Assumptions of Variables}

The conversion factor $\alpha$ of $0.583 \mathrm{~kg}$ of $\mathrm{CO}_{2}$-eq $/ \mathrm{kg}$ of $\mathrm{DM}$ is equal to $23 \mathrm{~g}$ of methane $/ \mathrm{kg}$ of $\mathrm{DM}$, similar to Bell and colleagues' (2016) estimates of 19.8 to $25.3 \mathrm{~g}$ of methane $/ \mathrm{kg}$ of DM. The energy per unit of DM (MJ of $\mathrm{ME} / \mathrm{kg}$ of $\mathrm{DM}$ ) assumptions of 10.41 to 11.7 were similar to Bell and colleagues' (2016) estimates of 11.4 to 11.6 metabolizable energy. The replacement feed intake energy estimate of $30,827 \mathrm{MJ}$ of ME is similar to Bell and colleagues' (2016) estimates of 30,434 MJ of ME. The annual cow feed intake energy estimate of 49,595 MJ of ME (combining on-platform and off-platform energy requirements) is lower than the estimates of Bell et al. (2016) of 78,007 MJ of ME per lactating cow, which is reasonable, considering New Zealand dairy cows are fed on pasture and have a longer winter break, and thus consume less energy and produce less compared with dairy cows from other countries. The average BW estimate of $450 \mathrm{~kg}$ is smaller than that found in other studies (500 kg estimated by Bell et al., 2016, and 547 $\mathrm{kg}$ estimated by Bell et al., 2013), which is reasonable because New Zealand dairy cows are smaller than UK dairy cows due to a significant contribution of the Jersey breed, with its small mature size, to the total population and a history of strong selection pressure toward moderate mature size. The milk protein and fat percentage estimates of $3.91 \%$ and $4.85 \%$ are slightly larger than the estimates of $4.02 \%$ and $3.91 \%$ by Bell et al. (2013), reflecting a long selection history for milk solids production in New Zealand.

\section{Context}

The current NBO target increases in milk fat, milk protein, live weight, fertility, survival, and BCS, and low SCS (DairyNZ, 2019). Milk volume, which increases 
transport and processing costs, is increasing due to its unfavorable correlations with milk fat and milk protein. In this study we evaluated the possible consequences of current selection practices on methane emissions: we evaluated the effect on methane emissions of each NBO trait separately and then combined these with recent estimates of genetic trends to obtain an aggregated effect of genetic improvement on key trends.

In general, increasing milk production and cow live weight increases the overall feed intake of cows, hence increasing per-cow gross methane emissions. In contrast, increases in cow survival and productive life decrease gross methane emissions, through reductions in feed intake and emissions associated with a lower need to rear herd replacements. This effect is partly compensated for by an older herd, with more of the herd achieving milk production levels of mature cows also consuming more feed per cow in the herd.

Per-cow methane emissions are somewhat irrelevant in a genetic improvement context when the farming system is based primarily on feed supplied through grazing. In these situations, genetic changes in per-cow feed requirements may result in changes in stocking rate per hectare. Furthermore, from a national inventory perspective, the impact of genetic improvement on methane emissions per hectare is of specific interest in New Zealand, because the number of hectares of farmland devoted to dairy farming is more likely to be constant and predictable than the number of dairy cows. In particular, with environmental regulations having effectively put a stop to recent increases in the number of hectares devoted to dairy farming in New Zealand, the number of cows farmed may well decrease in the future, as milk production potential and associated percow feed requirements increase, but the total emissions from dairy farming will not be decreasing (Radio New Zealand, 2018).

Emissions per unit of product (i.e., emissions intensity) as a metric of methane production is relevant from a global perspective, particularly because the New Zealand dairy industry has a lower emissions intensity per unit of milk product output than do the majority of its major export markets (Gao et al., 2011; Bell et al., 2013; DCANZ, 2018). From a global perspective, if New Zealand were to reduce its milk product output as a result of policies or breeding directions to reduce emissions at a national industry level, the net effect on global emissions would be unfavorable if the reduced output from New Zealand was consequently replaced with new milk product output from other countries with higher emissions intensity.

In this study, we observed that genetic selection in the New Zealand dairy cow population is contributing to ongoing efficiency gains through higher productivity, net gains in feed efficiency, and consequently, improved emissions intensity. However, from a national perspective, New Zealand has an obligation to the global community to play its part in reducing greenhouse gas emissions, and a substantial proportion of current emissions comes from dairy (NZAGRC, 2012; Ministry for the Environment, 2019). The evidence from this study is that genetic improvement according to current trait trajectories is unlikely to result in a reduction in national dairy industry emissions. Further, to the extent that increases in milk production genetic potential encourage farmers to supplement cows with high-quality feeds grown in areas not traditionally used for dairy production, genetic improvement could potentially make the national inventory situation worse.

\section{CONCLUSIONS}

With selection under the current breeding objective, gross methane emissions from the New Zealand dairy sector are predicted to grow on a per-cow basis but stay relatively static if stocking rate declines, to compensate for additional feed requirements, and if the total number of hectares in dairy production remains static. Because the current selection direction results in ongoing improvements in milk production efficiency, the emissions of methane per unit of product (i.e., emissions intensity) will continue to improve significantly. New selection criteria that result in reduced methane emissions per hectare will be required if dairy cow genetic improvement is going to contribute significantly to New Zealand achieving stated target GHG emissions.

\section{ACKNOWLEDGMENTS}

Funded by the New Zealand Government to support the objectives of the Livestock Research Group of the Global Research Alliance on Agricultural Greenhouse Gases. The authors acknowledge NZAEL for use of the National Breeding Objective model.

\section{REFERENCES}

Amer, P. R., F. S. Hely, C. D. Quinton, and A. R. Cromie. 2018. A methodology framework for weighting genetic traits that impact greenhouse gas emissions intensities in selection indexes. Animal 12:5-11. https://doi.org/10.1017/S1751731117001549.

Amer, P. R., B. Santos, T. Byrne, C. Ludemann, B. Visser, B. L. Harris, and J. Bryant. 2013. An update of the national breeding objective for the New Zealand dairy industry. Interbull Bull. 47:95-98.

Bell, M. J., R. J. Eckard, M. Haile-Mariam, and J. E. Pryce. 2013. The effect of changing cow production and fitness traits on net income and greenhouse gas emissions from Australian dairy systems. J. Dairy Sci. 96:7918-7931. https://doi.org/10.3168/jds.2012-6289.

Bell, M. J., J. Pryce, and P. Wilson. 2016. A comparison of the economic value for enteric methane emissions with other biological 
traits associated with dairy cows. ARJA. 2:1-17. https://doi.org/ 10.21694/2379-1047.16002.

Breider, I. S., E. Wall, P. C. Garnsworthy, and J. E. Pryce. 2018. Genetic relationships between methane emission and milk yield, live weight and dry matter intake. Proc. 11th World Congress of Genetics Applied to Livestock Production, Auckland, New Zealand.

Byrne, T., B. Santos, P. R. Amer, and J. R. Bryant. 2013. The economic value of body condition score in New Zealand seasonal dairy systems. Proc. Assoc. Advmt. Anim. Breed. Genet. 20:479-482.

Capper, J. L., R. Cady, and D. Bauman. 2009. The environmental impact of dairy production: 1944 compared with 2007. J. Anim. Sci. 87:2160-2167. https://doi.org/10.2527/jas.2009-1781.

DairyNZ (New Zealand Dairy Industry). 2017. New Zealand Dairy Statistics 2016-2017. Accessed Oct. 31, 2018. https://www.dairynz .co.nz/publications/dairy-industry/new-zealand-dairy-statistics $-2016-17 /$.

DairyNZ (New Zealand Diary Industry). 2018. Breeding worth explained. Accessed Sep. 21, 2019. https://www.dairynz.co.nz/ media/5789109/nzael_breeding_worth_your_index_feb_2018.pdf.

DairyNZ (New Zealand Dairy Industry). 2019. All about BW. Accessed Sep. 21, 2019. https://www.dairynz.co.nz/animal/animal -evaluation/interpreting-the-info/all-about-bw/.

DCANZ (Dairy Companies Association of New Zealand). 2018. About the NZ dairy industry. Accessed Nov. 26, 2018. https://www.dcanz .com/about-the-nz-dairy-industry/.

Fennessy, P. F., T. J. Byrne, L. E. Proctor, and P. R. Amer. 2018. The potential impact of breeding strategies to reduce methane output from beef cattle. Anim. Prod. Sci. 59:1598-1610. https://doi.org/ 10.1071/AN18186.

Gao, Z., H. Yuan, W. Ma, X. Liu, and R. Desjardins. 2011. Methane emissions from a dairy feedlot during the fall and winter seasons in Northern China. Environ. Pollut. 159:1183-1189. https://doi.org/ 10.1016/j.envpol.2011.02.003.

Harris, B. L. 2005. Multiple trait fertility model for national genetic evaluation. Livestock Improvement Corporation:1-24. Hamilton, New Zealand. http://s3.amazonaws.com/zanran_storage/www .aeu.org.nz/ContentPages/16616596.pdf.

Harville, D. A., and C. R. Henderson. 1967. Environmental and genetic trends in production and their effects on sire evaluation. J. Dairy Sci. 50:870-875.

Jonker, A., S. M. Hickey, S. J. Rowe, P. H. Janssen, G. H. Shackell, S. Elmes, W. E. Bain, J. Wing, G. J. Greer, and B. Bryson.. 2018. Genetic parameters of methane emissions determined using portable accumulation chambers in lambs and ewes grazing pasture and genetic correlations with emissions determined in respiration chambers. J. Anim. Sci. 96:3031-3042. https://doi.org/10.1093/ jas/sky187.

Kandel, P. 2018. Genetic relationships between methane-related traits and milk composition in lactating dairy cows. $\mathrm{PhD}$ dissertation. Gembloux Agro-Bio Tech, Université de Liège, Liège, Belgium.

Ministry for the Environment. 2019. New Zealand's Greenhouse Gas Inventory 1990-2017. Wellington, New Zealand. https://www.mfe .govt.nz/publications/climate-change/new-zealands-greenhouse -gas-inventory-1990-2017.

Muehlhoff, E., A. Bennett, D. McMahon, and Associates. 2013. Milk and Dairy Products in Human Nutrition. Food and Agriculture Organization of the United Nations (FAO). Rome, Italy. Accessed Mar. 6, 2019. https://www.fao.org/3/i3396e/i3396e.pdf.
NZAEL (New Zealand Animal Evaluation Limited). 2013. Somatic Cell Score. Accessed Sep. 21, 2019. https://www.dairynz.co.nz/ media/928759/SCC-Economic-Model.pdf.

NZAGRC (New Zealand Agriculture GREENHOUSE GAS Research Centre). 2012. Economic and Policy Implications of Alternative GHG Metrics. NZAGRC Factsheet 3. Palmerston North, New Zealand. Accessed Mar. 6, 2019. https://www.nzagrc.org.nz/fact -sheets, listing, 95 ,economic-and-policy-implications-of-alternative -ghg-metrics.html.

New Zealand Productivity Commission. 2018. Low-emissions economy: Final report. Accessed Oct. 31, 2018. https://www.productivity .govt.nz/sites/default/files/Productivity\%20Commission_Low -emissions\%20economy_Final\%20Report_FINAL.pdf.

Nicol, A., and I. Brookes. 2007. The metabolisable energy requirements of grazing livestock. Occasional Publication. Pages 151-172 in Pasture and Supplements for Grazing Animals. Vol. 14. P. V. Rattray, I. M. Brookes, and A. M. Nichol, ed. New Zealand Society of Animal Production, Hamilton, New Zealand.

Pickering, N. K., M. G. Chagunda, G. Banos, R. Mrode, J. C. McEwan, and E. Wall. 2015. Genetic parameters for predicted methane production and laser methane detector measurements. J. Anim. Sci. 93:11-20. https://doi.org/10.2527/jas.2014-8302.

Quinton, C. D., F. S. Hely, P. R. Amer, T. J. Byrne, and A. R. Cromie. 2018. Prediction of effects of beef selection indexes on greenhouse gas emissions. Animal 12:889-897. https://doi.org/10.1017/ S1751731117002373.

Radio New Zealand. 2018. Farmers may be forced to reduce cattle numbers. Accessed Nov. 26, 2018. https://www.radionz.co.nz/ news/national/356750/farmers-may-be-forced-to-reduce-cattle -numbers.

Rattray, P. V., I. Brooks, and A. M. Nicol. 2007. Pasture and supplements for grazing animals. Occasional Publication No. 14. New Zealand Society of Animal Production, Hamilton, New Zealand.

Richardson, C. 2018. Breeding for efficiency: Investigating dairy cattle efficiency traits and future implementation strategies. J. Anim. Sci. 96 (Suppl. 3):119-120. (Abstr.) https://doi.org/10.1093/jas/ sky404.263.

Richardson, C. M., C. F. Baes, P. R. Amer, C. Quinton, P. Martin, V. R. Osborne, J. E. Pryce, and F. Miglior. 2019. Determining the economic value of daily dry matter intake and associated methane emissions in dairy cattle. Animal Jul. 22 (epub):1-9. https://doi .org/10.1017/S175173111900154X.

Rowe, S. J., S. Kittelmann, C. Pinares-Patiño, G. R. Wood, K. G. Dodds, M. R. Kirk, S. Ganesh, S. M. Hickey, P. H. Janssen, and J. C. McEwan. 2015. Brief communication: Genetic control of the rumen microbiome in sheep. Page 67-69 in Proc. 75th N. Z. Soc. of Anim. Prod., Dunedin, New Zealand. Accessed Sep. 21, 2019. http: //www.nzsap.org/proceedings/2015/brief-communication-genetic -control-rumen-microbiome-sheep.

\section{ORCIDS}

X. Zhang $\odot$ https://orcid.org/0000-0002-6439-2782

P. R. Amer ๑ https://orcid.org/0000-0002-6428-7165

C. Quinton ( https://orcid.org/0000-0001-6824-4624 